\title{
Caveat emptor
}

Jeffrey Michel, MD

Division of Cardiology, Scott and White Medical Center, Temple, Texas

\section{KEYWORDS Health insurance; satire; policy}

$\mathrm{t}$ is hard to believe there was a time when we didn't have comprehensive car care insurance. People lived in fear, just one catastrophic car failure away from possible job loss and financial ruin. Fortunately, thanks to the tireless lobbying efforts of "Americans for Car Care Now," a nongovernmental organization backed by progressive car care providers and the car care industry, comprehensive car care insurance (CCCI) is now the law of the land. Thanks to CCCI, you can drive to work knowing that you are fully protected. \$500 a month is a small price to pay for peace of mind. And, importantly, you no longer need to worry about the occasional low-pitched squeaking noise coming from somewhere behind the back seat.

All you do is schedule an online appointment and go to your car care home, usually found at the local gas station. There, care is coordinated by your designated primary car care professional (PCCP). All you do is tell $\mathrm{Al}$ that your car is making a funny noise, and he takes care of it.

Having $\mathrm{Al}$ as your PCCP is a joy. He is highly rated (99.8\%) on the federal car care professional freedom to know (www.PCCPFK.org) website, with $100 \%$ ratings in empathy and time spent listening. When you visit to discuss the squeak, he asks about your job and your pet poodle and reminds you that you should exercise and eat more fruits and vegetables. $\mathrm{He}$ looks your car over and asks when the noise started and how long it lasts. He taps on the hood and listens to your gas cap. Does anything make it better or worse? He tells you that he had a lady once with a car that made a noise just like yours. It turned out to be a muffler problem. He hugs you on the way out the door and assures you that he is there for you and your car.

$\mathrm{Al}$ refers you to a muffler shop run by his cousin Jill, who many consider the best in town. You drive to her office and agree to have her check your muffler. Over the next week, you bring your car back three times for tests, including one in which it is placed in a large box that shakes vigorously while bombarding it with high-intensity radiation. During that test technicians in heavy lead-lined suits advise you to stand a good distance away from the building. You are told to return in 6 weeks for the results. No news is probably good news. The bills arrive. Your insurance is charged $\$ 4500$ for the visit and the testing, but you are only on the hook for $\$ 200$ as your copay. Thank goodness for your insurance.

Four weeks pass. On the appointed day, you are ushered into a small room in the muffler specialist's office. She enters wearing a white lab coat and carrying a plastic model of what you assume is a muffler and explains that the finkle shaft of the duzzle manifold is out of alignment. "Normal is 10-15 degrees and yours is $20 \%$." You nod so as not to appear stupid. She recommends a new muffler and that you are in luck. A spot has just opened up on her schedule in 6 weeks at 7:00 AM on a Wednesday. You are not to drive the day before and to arrive 2 hours early so that they can verify your insurance and allow time to cover the copayment. Credit cards are accepted but no cash or checks.

You ask how much it will cost and are told not to worry. Your comprehensive car care insurance will pay. You are told that pricing is proprietary information that cannot be disclosed to car owners. It is a matter between your car care professional and your insurance company. You needn't give it a second thought.

Your muffler is replaced. But your car still makes the noise. You receive a bill for $\$ 32,000$ including $\$ 21,000$ for the muffler. The rest is for installation. Looking online, you find that a muffler in India made by the same manufacturer costs $\$ 100$ and can be installed for $\$ 50$. You find videos on YouTube showing people making and installing their own mufflers. But you have no interest in becoming a criminal. State and federal laws prevent anyone not certified by the American Muffler Replacement Association from performing that work.

You attend a follow-up session with Jill and are told that your muffler replacement was a success. While you may still hear a funny noise, the good news is that you no longer need to worry about misalignment. You ask about a refund and there is an awkward silence.

You return to see your PCCP Al who shows you pictures from his family's recent trip to Costa Rica, asks how you are

Corresponding author: Jeffrey Michel, MD, Division of Cardiology, Scott and White Medical Center, 2401 S. 31st Street, Temple, TX 76508 (e-mail: jeffrey. michel@BSWHealth.org) 
doing with the exercise, fruits, and vegetables, and tells you that he once saw a car in car care school that had a funny noise that turned out to be the transmission. He is a great guy and really does care about you and your car. You make sure to rate him a 10 out of 10 when you receive a survey in the mail a week later.

$\mathrm{Al}$ refers you to the best transmission shop in town, which is conveniently located nearby and is part of the car care network that employs him. The network is comprehensive, and you feel lucky to be a part of it. They have specialists in brakes, odometers, and hood ornaments all in the same building as the transmission guy.

All the specialists use the same electronic car record system that $\mathrm{Al}$ uses. This makes sharing information about you and your car a snap. After replacing the transmission, the noise persists but seems to be less high pitched. You go on to replace the brake pads, the odometer, and finally your hood ornament. Fortunately, after getting preauthorization, your insurance agrees to cover a consultation by a fuel specialist. This is a real God-send since there is only one in your area. Thankfully, he too is part of your PCCP's car care network. You begin weekly visits to his office, each culminating with addition of a proprietary supplement to your gas tank by an employee who is a certified gas supplement specialist (GSS). Wearing a special gold smock and goggles, the GSS carefully drips two to three ounces of the supplement into your gas tank each week for $\$ 100$ a pop. But, thanks to your insurance, you only pay $\$ 20$. After several months, the noise seems to lessen. During this time, you learn more about your car's condition by reading the brochures, pamphlets, and online educational modules sponsored by "Citizens Free and United," a foundation established and endowed by the manufacturer of the gas supplement.

Today you sit in a support group with other individuals suffering from what is now recognized as irritable car syndrome (ICS). Guidelines published just this year by the American Association of Car Care Professionals clearly define the disorder:

Irritable car syndrome (ICS) is a common disorder of unknown etiology. Only a small number of cars with ICS have severe signs and symptoms. Some drivers can control symptoms by managing their diet, lifestyle, and stress. Others will need professional car care and counseling.

But you are a survivor! Counseling sessions are paid for by insurance, less a copay of $\$ 20$ so long as you don't exceed four sessions a month. When notified that your premium will increase next year, you take it in stride, happy to have the services and expertise of a caring group of car care providers and reminded to be thankful for comprehensive car care insurance. 